\title{
Rancang Bangun Alat Ukur Tinggi Badan Otomatis Berbasis Arduino Uno R3 Menggunakan Sensor Ping Parallax Ultrasonic Dengan Tampilan Lcd (Liquid Crystal Display) Dan Suara
}

\author{
Habibi Azka Nasution dan Khairul Amdani* \\ Jurusan Fisika, Fakultas Matematika dan Ilmu Pengetahuan Alam, Universitas \\ Negeri Medan, Indonesia
}

Diterima April 2016; Disetujui Mei 2016; Dipublikasikan Juni 2016

\begin{abstract}
Abstrak
Penelitian ini bertujuan untuk mengetahui tinggi badan manusia dengan menggunakan alat ukur digital. Sensor PING Parallax Ultrasonic digunakan sebagai pendeteksi objek. Arduino Uno R3 yang digunakan sebagai basis utama pengendalian sistem dan pengolahan data dari sensor dengan mikrokontroler ATMega 328. Sensor memancarkan sinyal pada Trigger. Apabila sinyal mengenai objek maka akan dipantulkan pada bagian Echo. Hasil dari pengukuran yang telah diolah pada bagian Arduino Uno R3 ditampilkan pada LCD (Liquid Crystal Display) dan suara. Alat yang dirancang terlebih dahulu diuji kepekaannya untuk mendeteksi jarak kemudian diaplikasikan untuk pengukuran tinggi badan manusia. Hasil pengujian kepekaan alat memiliki persentase kesalahan sebesar $1.51 \%$ dengan nilai korelasi sebesar 0.99 . Hasil dari pengukuran tinggi badan manusia memiliki persentase kesalahan $0.46 \%$ dengan selang kepercayaan bagi rata - rata perhitungannya alat mampu bekerja dengan baik pada rentang 135,48 cm hingga 181,22 cm dengan tingkat kepercayaan 95 $\%$, maka alat ukur tinggi badan manusia ini dapat dipergunaakan untuk mengganti alat yang konvensional.
\end{abstract}

Kata kunci : Ping Parallax Ultrasonic, Arduino Uno R3, Trigger, Echo

\begin{abstract}
This research aims to know the human height by using the digital gauge. Parallax PING Ultrasonic sensors is used as object detection. Arduino Uno R3 which is used as the main base of control system and data processing of sensor with a microcontroller ATMEGA 328. The sensor transmit a signal on the Trigger. When a on the object it will be reflected in the Echo. The results of the measurements that have been processed
\end{abstract}


Habibi Azka Nasution dan Khairul Amdani, Rancang Bangun Alat Ukur Tinggi Badan Otomatis Berbasis Arduino Uno R3 Menggunakan Sensor Ping Parallax Ultrasonic Dengan Tampilan Lcd (Liquid Crystal Display) Dan Suara

at the Arduino Uno R3 displayed on the LCD (Liquid Crystal Display) and sound. A tool designed tested sensitivity to detect the distance and then applied for the measurement of a man. Results of testing the sensitivity of the instrument have a percentage error of $1.51 \%$ to the value of the correlation of 0.99 . The results of the measurement of human height has a percentage of errors with the confidence interval $0.46 \%$ for average calculation tool capaable of averaging works well on the range $135.48 \mathrm{~cm}$ to $181.22 \mathrm{~cm}$ with a confidence level $95 \%$, so the human height gauge can be used to replace a conventional tool.

Keywords : Ping Parallax Ultrasonic, Arduino Uno R3, Trigger, Echo

How to Cite: Habibi Azka Nasution dan Khairul Amdani, (2016), Rancang Bangun Alat Ukur Tinggi Badan Otomatis Berbasis Arduino Uno R3 Menggunakan Sensor Ping Parallax Ultrasonic Dengan Tampilan Lcd (Liquid Crystal Display) Dan Suara, Jurnal Einsten Prodi Fisika FMIPA Unimed, 4 (2) : 23-31.

\begin{tabular}{ll}
\hline *Corresponding author: & p-ISSN : I2338 - 1981 \\
E-mail : habibiazka3@gmail.com & e-ISSN : 2407 - 747x
\end{tabular}




\section{PENDAHULUAN}

Teknologi merupakan salah satu hal yang banyak diperbincangkan di era globalisasi ini. sejak dahulu teknologi sudah ada atau manusia sudah menggunakan teknologi. Teknologi sebagai keseluruhan metode yang secara rasional mengarah dan memiliki ciri efisiensi dalam setiap bidang kegiatan manusia. Terkait dengan pengertian teknologi tersebut terdapat salah satu masalah di dalamnya, misalnya untuk melakukan sesuatu kegiatan yang memakai alat sangat dibutuhkan kefesiensiannya. Hal ini terkait dengan masalah waktu. Zaman globalisasi telah membawa perubahan pada teknologi, dimana penggunaan teknologi sudah beralih dari sifat konvensional ke digital.

Salah satu aktivitas yang memakai teknologi yang konvensional ialah terkait masalah pengukuran tinggi badan manusia. Pengukuran tinggi badan manusia juga merupakan salah satu indikasi dari kesehatan seseorang. Tinggi badan adalah ukuran antropometri yang meggambarkan keadaan pertumbuhan skeletal (Hardinsyah, dkk. 2008). Tinggi badan merupakan salah satu indikator klinik utama dalam menentukan indeks massa tubuh (IMT) dalam menentukan status gizi individu atau populasi sehingga pengukuran tinggi badan seseorang secara akurat sangatlah penting (Fatmah, 2006). Menurut (Morris, 2001) pengukuran tinggi badan adalah hal mendasar yang digunakan untuk mengubah suatu kuantitias dan untuk menetapkan aturan yang jelas mengenai nilai - nilai yang relative untuk komoditas yang berbeda. Sistem awal untuk pengukuran didasari pada hal - hal yang terdapat dalam setiap unit pengukuran.

Alat ukur tinggi badan yang sering digunakan saat ini yaitu alat ukur tinggi badan analog.Maka dari itu untuk mempercepat pengukurannya dibutuhkanlah suatu alat yang dapat mengukur dengan efisiensi waktu yang cepat. Alat ukur dengan penampil digital memberikan banyak kemudahan seperti pembacaan yang lebih teliti dan mudah dibaca. Pengolahan data juga lebih mudah dilakukan secara digital, walaupun ada beberapa aspek yang memang tidak bisa mengabaikan suatu alat ukur analog (A. Ejah Umraeni Salam, dan Cristophorus Yohannes, 2011). (Edi Setiawan, 2009) pada penelitiannya berhasil membuat alat ukur tinggi badan digital dengan menggunakan sensor ultrasonik. Sedangkan untuk pengolahan datanya menggunakan mikrokontroler ATMega 16 diprogram menggunakan bahasa $\mathrm{C}++$. Hasil pengukurannya ditampilkan pada layar LCD (Liquid Crystal Display), dan konstruksi alat sepanjang $200 \mathrm{~cm}$. Sensor yang digunakan memliki ketelitian membaca adanya objek antara 2-3 cm, sedangkan untuk jarak yang dapat diterima sensor adalah $300 \mathrm{~cm}$. Sehingga hasil akhir dari penelitian ini didapat sebuah alat ukur tinggi badan yang mampu mengukur objek dengan ketelitian sensor untuk pembacaan data bernilai $197 \mathrm{~cm}$ tinggi maksimal dan $110 \mathrm{~cm}$ untuk tinggi minimal. Tingkat kesalahan alatnya setelah rata-rata total adalah sebesar 0,37\%. (Pratama, dkk. 2012) merancang sistem akuisisi data kinerja sensor ultrasonik berbasis sistem komunikasi serial menggunakan mikrokontroler ATMega 32. Perangkat sistem ini terdiri dari sebuah modul sensor ultrasonik PING. Metode dalam penelitian ini dilakukan dengan cara mengukur kinerja sensor ultrasonik terhadap beberapa material, seperti objek benda berwarna hitam, objek benda berwarna putih, kaca dan permukaan objek yang tidak rata. Dari hasil pengujian terlihat jarak hasil pengujian pada sistem tidak tepat sama dengan jarak hasil pengukuran terhadap obyek benda hitam dengan persen kesalahan antara 0.6\% hingga 14,40\%, terhadap objek benda putih persen kesalahan antara 1\% hingga 14,46\%, dan terhadap objek kaca persen kesalahan antara $0.6 \%$ hingga $14,40 \%$, serta pengujian terhadap objek dengan permukaan yang tidak rata akan mendeteksi jarak terjauh dari posisi objek 
Habibi Azka Nasution dan Khairul Amdani, Rancang Bangun Alat Ukur Tinggi Badan Otomatis Berbasis Arduino Uno R3 Menggunakan Sensor Ping Parallax Ultrasonic Dengan Tampilan Lcd (Liquid Crystal Display) Dan Suara

didepan sensor. Secara umum, semakin jauh jarak yang diukur, semakin besar persen kesalahan.

Berdasarkan uraian di atas, dapat dijadikan sebagai suatu indikator dalam pembuatan alat ukur tinggi badan dengan improvisasi sistem baik secara input, basis pengolahan data, dan output, tetapi memiliki tujuan yang utuh dalam menghasilkan nilai yang akurat yang dihasilkan oleh alat ukur tersebut. Alat ukur tinggi badan dapat dirancang dengan memanfaatkan berbagai modul pengontrol perangkat keras, salah satunya ialah Arduino Uno R3. Di dalam arduino terdapat sebuah mikrokontroler yang sangat bermanfaat dalam pengontrolan perangkat keras yaitu mikrokontroler ATMega 328, dengan sejumlah fitur di antaranya On-Hip System Debug, 5 ragam tidur (SleepMode), 6 saluran ADC (Analog Digital Converter) yang mendukung reduksi derau, ragam hemat daya (Powersave Mode, Power-down), dan ragam siaga (Standby Mode).

Maka dari ulasan tersebut, penulis bermaksud untuk merancang sebuah alat ukur tinggi badan dengan modul Arduino R3, sensor PING Parallax Ultrasonic.Judul penelitian yang diteliti adalah "Rancang Bangun Alat Ukur Tinggi Badan Otomatis Berbasis Arduino Uno R3 Menggunakan Sensor PING Parallax Ultrasonic dengan Tampilan LCD (Liquid Crystal Display) dan Suara."

\section{Batasan Masalah}

Berdasarkan masalah di atas, maka batasan masalah pada penelitian adalah :

1. Alat yang dirancang berupa pengukur tinggi badan manusia secara otomatis.

2. Alat yang dirancang menggunakan modul Arduino Uno R3.

3. Sensor pendeteksi menggunakan sensor PING Parallax Ultrasonic.
4. Rancangan perangkat lunak (software) dengan menggunakan bahasa processing dan writing platform atau yang lebih dikenal dengan bahasa $\mathrm{C}$.

5. Informasi sinyal output yang dihasilkan ditampilkan pada layar LCD (Liquid Crystal Display) dan suara.

\section{Rumusan Masalah}

Adapun rumusan masalah dalam penelitian ini sebagai berikut:

1. Bagaimana membuat alat ukur tinggi badan manusia secara otomatis?

2. Bagaimana rancangan sistem alat ukur tinggi badan otomatis berbasis Arduino Uno R3 menggunakan sensor PING Parallax Ultrasonic dengan Tampilan LCD (Liquid Crystal Display) dan suara?

3. Bagimana respon alat terhadap output pengukuran?

\section{Tujuan Penelitian} untuk :

Penelitian ini bertujuan untuk

1. Membuat suatu alat ukur tinggi badan secara otomatis.

2. Mengetahui hasil rancangan alat ukur tinggi badan otomatis dengan menggunakan sensor PING dan modul Arduino Uno R3.

3. Mengetahui respon yang diberikan rangkaian sistem terhadap output pengukuran.

\section{Manfaat Penelitian} adalah :

Manfaat dari penelitian ini

1. Dapat menghasilkan alat yang dapat mengukur tinggi badan manusia secara otomatis.

2. Dapat membantu seseorang maupun lembaga-lembaga terkait (kesehatan, kepolisian, kemiliteran, kelautan, badan transmigrasi, dan lain 
sebagainya) dalam pengukuran tinggi badan manusia.

3. Dapat memberikan informasi bagi para peneliti untuk melakukan penelitian lanjutan.

\section{METODOLOGI PENELITIAN}

\section{Tempat dan Waktu Penelitian}

Penelitian ini dilaksanakan di laboratorium Fisika FMIPA Universitas Negeri Medan, yang beralamat di Jalan Willem Iskandar Pasar V Medan selama 2 bulan.

\section{Alat dan Bahan Penelitian}

2.1. Alat

Multimeter Masda YX-360TR, Komputer Compaq Presario CQ43, Tool kit, Penghisap timah.

\subsection{Bahan}

Bahan yang digunakan antara lain Arduino Uno R3, sensor PING Parallax Ultrasonic, modul suara, resistor.

\section{Rancangan Sistem}

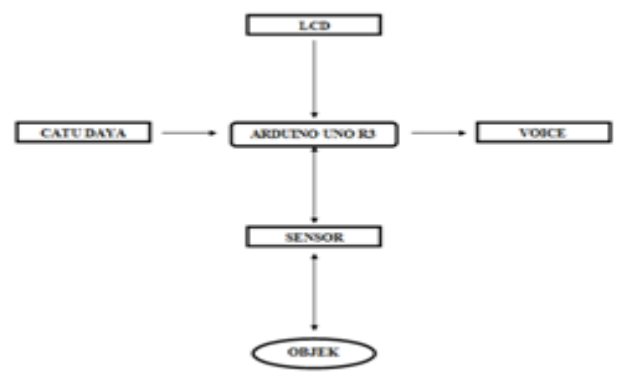

4. Analisis Data

Tahapan untuk analisis data, yaitu :

1. Data yang diperoleh pada tampilan LCD dan data yang diperoleh menggunakan alat ukur standar dimuat dalam tabel hasil pengukuran tinggi badan.

2. Persen error dan korelasi dari alat yang dirancang.

3. Pengujian Kepekaan PING Parallax Ultrasonic dengan Variasi Jarak.

4. Hubungan Jarak Ukur PING Parallax Ultrasonic dengan Waktu Tempuh.

5. Pengujian Modul Suara.
6. Pengukuran Terhadap Sampel.

\section{HASIL PENELITIANDAN PEMBAHASAN}

\section{Hasil Penelitian}

Alat ini terdiri dari bagian perangkat keras (hardware) dan perangkat lunak (software). Perangkat keras (hardware) terdiri dari sensor PING Parallax Ultasonic, modul Arduino Uno R3 dengan mikrokontroler ATMega 328, LCD (Liquid Crystal Display) 16x2, dan modul suara. Perangkat lunak (software) menggunakan bahasa processing dan writing platform atau yang lebih dikenal dengan bahasa $\mathrm{C}$.

Sensor Ultrasonic berfungsi sebagai pendeteksi objek. Sensor ini akan mengirimkan suara ultrasonik berupa sinyal pulsa dari bagian transmitter dengan frekuensi sebesar $40 \mathrm{kHz}$ dengan kecepatan rambat di udara $344 \mathrm{~m} / \mathrm{s}$ Apabila sinyal pulsa dari transmitter mengenai objek maka akan dipantulkan kembali ke bagian echo pada modul sensor Ultrasonic. Sinyal - sinyal pada sensor dibangkitkan dengan menggunakan tegangan sebesar 5 volt. Sehingga untuk mencapai tinggi pengukuran tertentu yang akan berubah adalah nilai waktu tempuh untuk mencapai objek, sedangkan tegangan tetap. Modul Arduino Uno R3 memiliki mikrokontroler ATMega 328 sebagai pusat kendali,

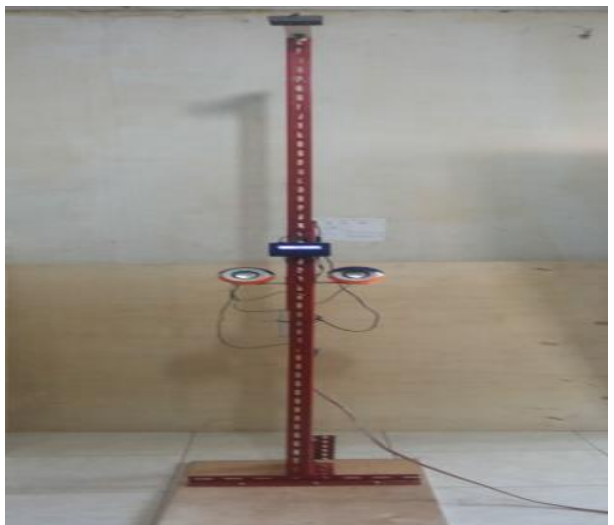

Gambar 1. Bentuk Fisik Alat

Ukur Tinggi Badan Otomatis

2. Pengujian Rangkaian Sensor PING Parallax Ultrasonic 
Habibi Azka Nasution dan Khairul Amdani, Rancang Bangun Alat Ukur Tinggi Badan Otomatis Berbasis Arduino Uno R3 Menggunakan Sensor Ping Parallax Ultrasonic Dengan Tampilan Lcd (Liquid Crystal Display) Dan Suara

Pada penelitian ini akan diteliti kepekaan sensor terhadap jangkauan jarak ukurnya dengan membandingkan jarak sebenarnya. Setelah kepekaan sensor didapatkan maka masing masing hasil pengukuran akan dihitung tegangan output dan waktu tempuh yang dihasilkan pada setiap pengukuran.

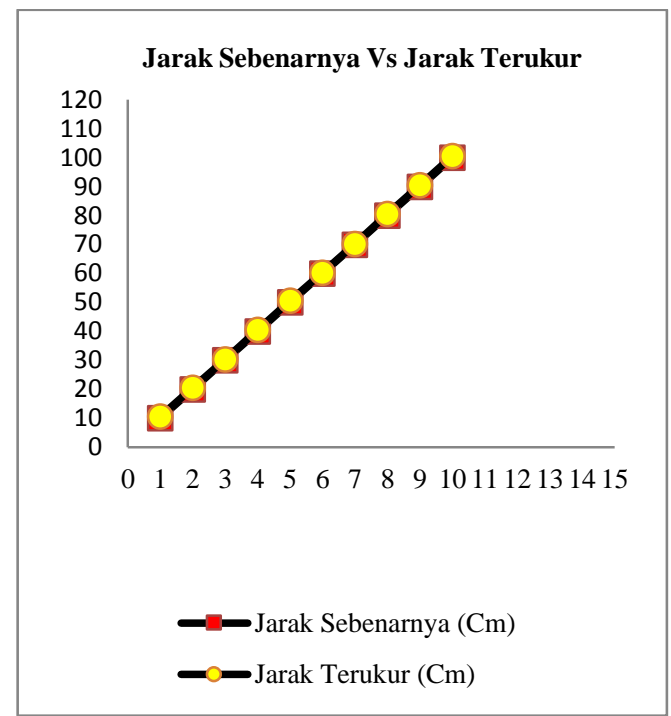

Gambar 2. Grafik Perbandingan Jarak Sebenarnya Vs Jarak Terukur

Hasil dari pengujian kepekaan sensor dengan variasi jarak, kemudian diidentifikasi berapa lama waktu yang dibutuhkan oleh sensor untuk mengenai objek. Waktu tempuh untuk mendeteksi objek berdasarkan persamaan, yaitu menghitung waktu kecepatan sinyal per $10 \mathrm{~cm}$ dengan perhitungan sebagai berikut.

$$
\begin{gathered}
\mathrm{s}=\frac{\left(\mathrm{v} \times \mathrm{t}_{\text {in }}\right)}{2} \\
\mathrm{t}_{\text {in }}=\frac{\mathrm{s}}{\mathrm{v}} \times 2 \\
\mathrm{t}_{\text {in }}=\frac{100000 \mu \mathrm{S}}{344 \mathrm{~m} / \mathrm{s}} \times 2 \\
\mathrm{t}_{\text {in }}=581.39 \mu \mathrm{S}
\end{gathered}
$$

Sehingga untuk mendeteksi objek pada jarak $10 \mathrm{~cm}$ sensor membutuhkan waktu tempuh $\left(\mathrm{t}_{\text {in }}\right)$ selama $581.39 \mu \mathrm{S}$. Tabel 4.3 ialah hasil pengujian waktu tempuh terhadap jarak ukur dari sensor.

Tabel 1. Hubungan Jarak Ukur PING Parallax Waktu Tempuh

\begin{tabular}{cccc}
\hline No & $\begin{array}{c}\text { Terukur } \\
(\mathbf{c m})\end{array}$ & $\begin{array}{c}\text { Waktu Tempuh } \\
\text { Pengamatan }(\boldsymbol{\mu} \mathbf{S})\end{array}$ & $\begin{array}{c}\text { Waktu } \\
\text { Tempuh } \\
\text { Fisik } \\
(\boldsymbol{\mu} \mathbf{S})\end{array}$ \\
\hline 1 & 10 & 634 & 581.39 \\
2 & 20 & 1211 & 1162.79 \\
3 & 30 & 1788 & 1744.18 \\
4 & 40 & 2365 & 2325.58 \\
5 & 50 & 2941 & 2906.97 \\
6 & 60 & 3519 & 3488.37 \\
7 & 70 & 3896 & 4069.76 \\
8 & 80 & 4473 & 4651.16 \\
9 & 90 & 5050 & 5232.55 \\
10 & 100 & 5627 & 5813.95 \\
\hline
\end{tabular}

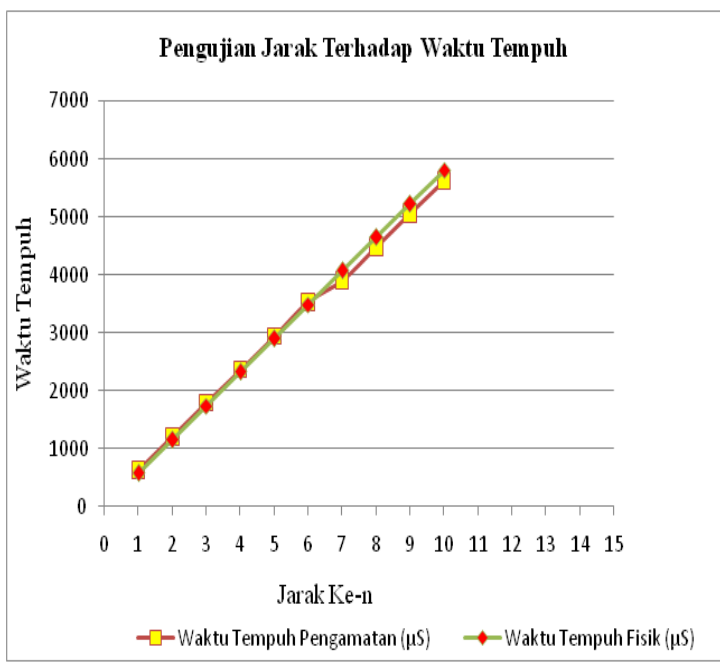

Gambar 3. Grafik Hubungan Jarak Terhadap Waktu Tempuh

\section{Pengujian Rangkaian Modul Suara}

Pengujian modul suara bertujuan untuk memastikan apakah informasi yang disampaikan sama dengan hasil ukur yang tampil pada layar LCD (Liquid Crystal Display).

Tabel 2. Hasil Pengujian Modul Suara

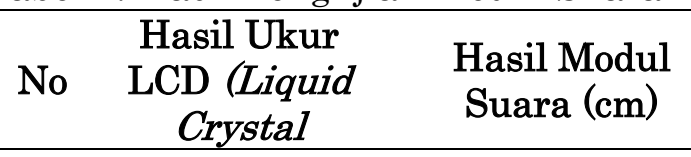




\begin{tabular}{ccc}
\hline \multicolumn{3}{c}{ Display)(cm) } \\
\hline 1 & 10 & 10 \\
2 & 20 & 20 \\
3 & 30 & 30 \\
4 & 40 & 40 \\
5 & 50 & 50 \\
6 & 60 & 60 \\
\hline \multicolumn{3}{c}{ Hasil Ukur } \\
No & LCD (Liquid & Hasil Modul \\
& Crystal & Suara (cm) \\
& Display)(cm) & \\
\hline 7 & 70 & 70 \\
8 & 80 & 80 \\
9 & 90 & 90 \\
10 & 100 & 100 \\
\hline
\end{tabular}

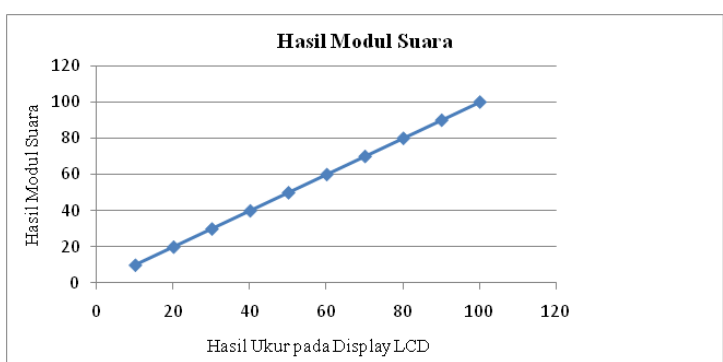

Gambar 4. Grafik Pengujian Hasil Modul

Suara Terhadap Hasil Ukur pada LCD

\section{Hasil Pengujian Alat}

\subsection{Kalibrasi Alat Ukur Tinggi Badan Manusia}

HT-H2 untuk mengetahui tinggi badan seseorang. Sehingga kalibrasi pada alat ukur tinggi badan ini menggunakan rumus:

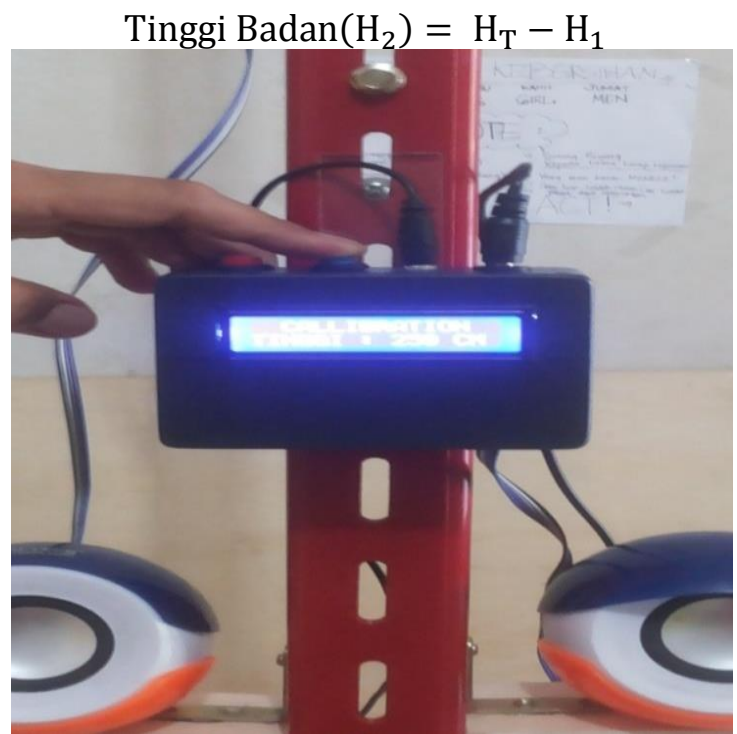

Gambar 6. Proses Kalibrasi Alat
Kalibrasi alat sangat perlu dilakukan karena mengingat permukaan tanah atau lantai yang tidak selalu rata. Maka dengan mengkalibrasi, alat ukur tinggi badan otomatis ini tetap dapat digunakan pada bidang yang tidak rata.

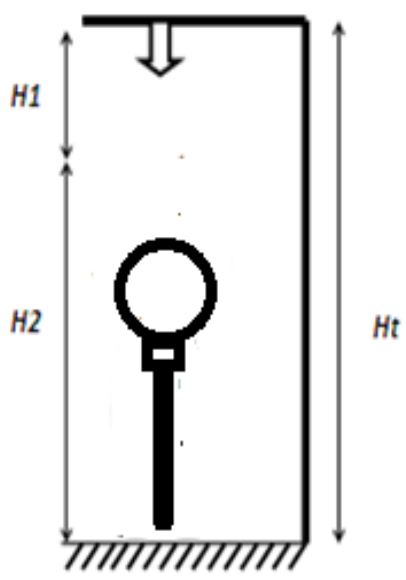

Gambar 5. Sket Kalibrasi

Fumgsi kalibrasi alat ukur tinggi badan otomatis ini tetap dapat digunakan pada bidang yang tidak rata. HT adalah tinggi sensor dengan tanah. Pada kode nanti, HT akan tertulis 250 (satuan $\mathrm{cm}$ ). Untuk $\mathrm{H} 1$ adalah jarak antara sensor dengan kepala atau obyek. Sedangkan H2 adalah

hasil

dari

\section{Hasil Pengujian Alat Terhadap Sampel (Tinggi Badan Manusia) \\ Langkah terkahir dalam penelitian} ini ialah menentukan nilai tinggi badan manusia menggunakan alat ukur analog dengan alat ukur yang dirancang. Hasil ukur dari alat akan dibandingkan dengan alat ukur standar. Persentase kesalahan alat yang dirancang melalui dua puluh lima objek dengan pengulangan lima belas kali setiap objek ialah sebear $0.46 \%$. 
Habibi Azka Nasution dan Khairul Amdani, Rancang Bangun Alat Ukur Tinggi Badan Otomatis Berbasis Arduino Uno R3 Menggunakan Sensor Ping Parallax Ultrasonic Dengan Tampilan Lcd (Liquid Crystal Display) Dan Suara

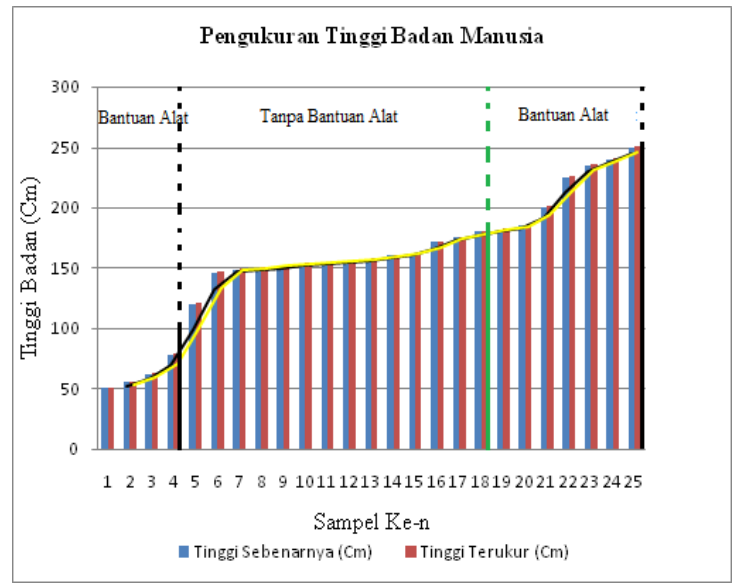

Gambar 7. Grafik Pengukuran Tinggi Badan Manusia

Standar deviasi untuk pengukuran tinggi badan manusia, yaitu tinggi sebenarnya ialah 53.76 dan tinggi pengkuran menggunakan alat yang dirancang memiliki nilai standar deviasi sebesar 53.68 .

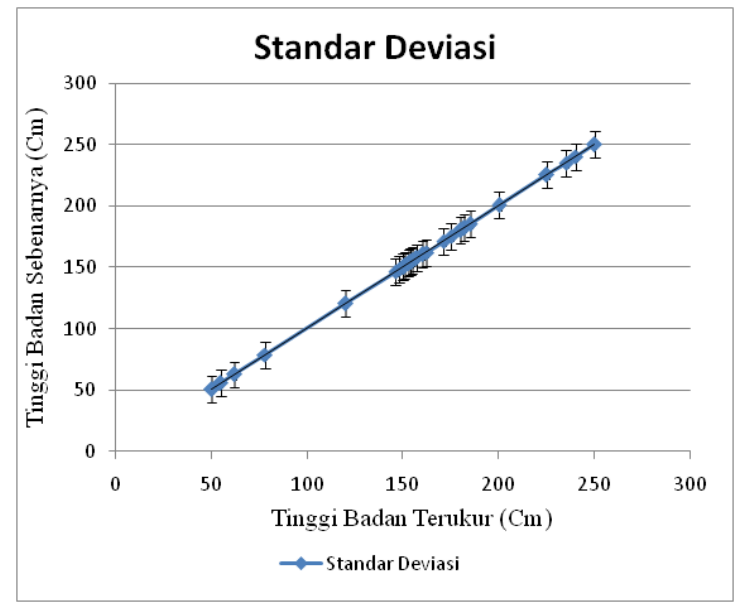

Gambar 8. Standar Deviasi Pengukuran

Alat

Pendugaan selang rata - rata digunakan untuk mengetahui tingkat kemampuan alat untuk mengukur tinggi badan manusia terhadap nilai minimum dan maksimumnya. Standar deviasi yang digunakan ialah dari pengukuran ratarata alat yang dirancang dengan persentase keakuratan alat yang diharapkan ialah sebesar $95 \%$.

Pendugaan selang rata-rata bila standart deviasi populasi tidak diketahui dengan jumlah sampel kecil $(\mathrm{n} \leq 30)$. Perhitungan digunakan standart deviasi dari pengukuran:

$$
\begin{gathered}
\bar{X}=158,35 \\
\alpha=1-0,95=0,05 \\
\mathrm{v}=\mathrm{n}-1=15-1=14 \\
\mathrm{t}=\frac{1}{2} \mathrm{\alpha}, \mathrm{v}=\mathrm{t}(0,025,25)=2,13 \\
\mathrm{SD}=53,69 \\
\mathrm{X} \pm \mathrm{t}(\mathrm{\alpha} / 2, \mathrm{v})\left(\frac{\mathrm{s}}{\sqrt{\mathrm{n}}}\right)
\end{gathered}
$$

Maka selang kepercayaan bagi rata-rata perhitungannya adalah :

$$
\begin{aligned}
& 158,352-(2,13)(10,74) \leq \mu \leq \\
& 158,35+(2,13)(10,74) \\
& 135,48 \leq \mu \leq 181,22
\end{aligned}
$$

Sehingga menurut perhitungan diatas, alat pengukur tinggi badan layak digunakan untuk mengukur tinggi dengan rentang 135,48 cm hingga 181,22 cm dengan tingkat kepercayaan $95 \%$. 
KESIMPULAN

Dari hasil penelitian yang
dilakukan maka dapat diambil
kesimpulan antara lain:

1. Alat yang dirancang dapat bekerja secara baik dan otomatis tanpa perlu melakukan peresetan ulang dalam pemakaiannya.

2. Hasil pengujian kepekaan alat memiliki persentase kesalahan sebesar $1,51 \%$, sedangkan persentase kesalahan hasil pengujian alat terhadap tinggi badan manusia bernilai $0.46 \%$.

3. Berdasarkan perhitungan selang kepercayaan bagi rata - rata perhitungannya alat mampu bekerja dengan baikpada rentang $135,48 \mathrm{~cm}$ hingga $181,22 \mathrm{~cm}$ dengan tingkat kepercayaan 95 $\%$, maka alat ukur tinggi badan manusia ini dapat dipergunaakan untuk mengganti alat yang konvensional.

\section{REFERENSI}

Fatmah, 2006. Persamaan (Equation) Tinggi Badan Manusia Usia Lanjut (Manula) Berdasarkan Usia Dan Etnis Pada Enam Panti Terpilih Di DKI Jakarta Dan Tangerang Tahun 2005, Jurnal Makara Kesehatan, Volume 10, No. 1, Juni 2006 : 716.

Hardinsyah, Evi Damayanthi dan Wirna Zulianti. 2008. Hubungan Konsumsi Susu Dan Kalsium Dengan Densitas Tulang Dan Tinggi Badan Remaja, Jurnal Gizi Dan Pangan, Volume 3 No. 1, Maret 2008:43-48.

Morris, S. A. 2001.Measurement and Instrumentation Principle. New Delhi: Butterwoth-Heinemann.

Pratama, Erik Haritman dan Tjetje Gunawan. 2012. Akuisisi Data
Kinerja Sensor Ultrasonik

Berbasis Sistem Komunikasi Serial Menggunakan

Mikrokontroler Atmega 32, Electrans, Vol.11, No.2, September 2012 , 36-43, ISSN 1412 - 3762.

Salam, A.E.U., dan Cristophorus Yohannes. 2011. Pengukur Tinggi Badan Dengan Detektor Ultrasonik, Prosiding 2011.

Setiawan, E. 2009.Alat Ukur Tinggi Badan Digital Menggunakan Ultrasonic Berbasis Mikrokontroler ATMega 16 Dengan Tampilan LCD,Jurnal Emitor, Vol. XI, No. 2, ISSN 141188 
Habibi Azka Nasution dan Khairul Amdani, Rancang Bangun Alat Ukur Tinggi Badan Otomatis Berbasis Arduino Uno R3 Menggunakan Sensor Ping Parallax Ultrasonic Dengan Tampilan Lcd (Liquid Crystal Display) Dan Suara 
Jurnal Einstein 4 (2) (2016): 23-31 